S.Ü. Müh. Bilim ve Tekn. Derg., c.6, s.3, ss. 519-528, 2018

Selcuk Univ. J. Eng. Sci. Tech., v.6, n.3, pp. 519-528, 2018

ISSN: 2147-9364 (Electronic)

SELÇUK

ÜNIVERSITESI

MÜHENDISLIK FAKÜLTESİ

DOI: 10.15317/Scitech.2018.149

\title{
MINERALOGICAL AND CHEMICAL CHARACTERISTICS OF THE AMPHIBOLE MINERALS FROM THE METAMORPHIC SOLE ROCKS OF THE LATE CRETACEOUS AGED HATIP OPHIOLITIC MÉLANGE IN THE KONYA AREA (CENTRAL SOUTHERN TURKEY)
}

\author{
${ }^{1}$ Kerim KOÇAK, ${ }^{2}$ Raziye Merve KAYA, ${ }^{3}$ Adnan DÖYEN, ${ }^{4}$ Ali Rıza SÖĞÜT, ${ }^{5}$ Veysel ZEDEF \\ 1,2,3,4 Selçuk University, Department of Geological Eng., Campus, Konya/TURKEY \\ ${ }^{5}$ Selçuk University, Department of Mining Eng., Campus, Konya/TURKEY \\ 1kkocak@selcuk.edu.tr, 2merve_7511@hotmail.com, ${ }^{3}$ adoyen@selcuk.edu.tr, ${ }^{4}$ arsogut@selcuk.edu.tr, \\ ${ }^{5}$ vzedef@selcuk.edu.tr
}

(Geliş/Received: 04.05.2017; Kabul/Accepted in Revised Form: 15.05.2017)

\begin{abstract}
In the Konya area, the Neotethyan assemblage is represented by Late Cretaceous aged Hatip Ophiolitic Mélange, in where the metamorphic sole rocks crop out as thin slices beneath the sheared serpentinites and harzburgites, and Çayırbağ 1 ophiolite. This study aims to characterize the mineralogical characteristics and chemical composition of the amphiboles in the metamagmatic sole rocks of the Hatıp Ophiolitic Mélange. The main rock types in the metamorphic sole rocks are amphibolite (amphibole up to $90.3 \%$ ); epidote-amphibolite (65.3\% amphibole); zoisite-amphibolite (amphibole 52.2\%) and amphibolequartzite (amphibole 28.5\%) with nematoblastic to porphyroblastic texture. The microprobe analyses of the amphiboles suggest that the amphiboles have crystallized from a wet magma in medium pressure condition $(\leq 7 \mathrm{~kb})$, and are magnesiohornblende, pargasite and edenite in composition. The obtained data also reveal that the Neotethyan assemblage has experienced a regional metamorphism in greenschist facies conditions, which resulted in no chemical changes in the amphiboles.
\end{abstract}

Key Words: Amphibolite, Konya, Metamorphic sole, Ophiolite

\section{Konya Yöresinde (Orta Güney Türkiye) Geç Kretase Yaşlı Hatip Ofiyolitik Melanjının Metamorfik Taban Kayaçlarındaki Amfibol Minerallerinin Mineralojik Ve Kimyasal Özellikleri}

ÖZ: Konya yöresinde Neotetis topluluğu, Geç Kretase yaşlı makaslanmış serpantinit ve harzburgitlerin altında ince dilimler şeklinde metamorfik taban kayaçlarının bulunduğu Hatıp ofiyolitik Melanjı ve Çayırbağı ofiyolitleri ile temsil edilirler. Bu çalışmada, metamorfik dilimde yer alan metamagmatik kayaçlardaki amfibollerin mineralojik özelliklerinin ve kimyasal bileşimlerinin ortaya konulması amaçlanmıştır. Metamorfik dilimdeki ana kayaç tipleri nematoblastik - porfiroblastik dokuya sahip olan amfibolit (\% 90.3 lere varan amfibol); epidot amfibolit (\%65.3 amfibol); zoisit amfibolit (\%52.2 amfibol) ve amfibol kuvarsit (\%28.5 amfibol) tir. Amfibollerin kimyası, amfibollerin orta basınç şartlarında $(\leq 7 \mathrm{~kb})$ sulu bir mağmadan kristalleşen magnezyohornblend, pargazit ve edenit bileşiminde olduğunu ortaya koymaktadır. Eldeki veriler, ayrıca Neotetis topluluğunun daha sonra amfibollerde kimyasal bir değişiklik oluşturmayan yeşilşist fasiyesi şartlarında bölgesel bir metamorfizmaya uğradığını vurgulamaktadır.

Anahtar Kelimeler: Amfibolit, Konya, Metamorfik dilim, Ofiyolit 


\section{INTRODUCTION}

The Konya area in south central Anatolia is important in understanding the evolution of both Paleotethyan and Neotethyan oceans. In the N-NW part of Konya city, Paleotethyan units are represented by pre-Permian tectono-stratigraphic/magmatic units (Eren, 1993; Eren et al., 2004; Goncuoglu et al., 2007; Özcan et al., 1990; Özcan et al., 1988; Robertson and Ustaomer, 2009), which are unconformably covered by Permian and Triassic sedimentary units (Goncuoglu et al., 2007; Özcan et al., 1988; Robertson and Ustaomer, 2009). The remnants of Neotethyan crop out in the SW part of Konya city, in where mélange and ophiolitic units of Late Cretaceous period cropp out (Figure 1, Figure 2). Of these, the Hatıp Ophiolitic Mélange contains both sedimentary and sheared serpentinite matrix in which huge blocks of limestones varying in age from Carboniferous to Late Cretaceous, radiolarian cherts, mudstone, and ophiolitic rocks are structurally dispersed. The mélange unit is tectonically overlain by an ophiolite body which includes serpentinized harzburgite with economically important hydrothermal magnesite deposits, dunite, pyroxenite and gabbro.

Metamorphic rocks forms locally at the base of the harzburgite blocks in the Hatıp Ophiolitic Mélange to the SW of Konya city. These metamorphic rocks are possibly the dismembered remnants of a metamorphic sole. The scope of this paper is (1) to determine the mineralogical and chemical characteristics of the amphiboles and (2) to constrain the conditions of amphibole crystallization in metamagmatic rocks of the metamorphic slice from the ophiolitic mélange in the Karadigin (Meram, Konya) area.

\section{GEOLOGICAL SETTING AND PETROGRAPHY}

The investigation area is located in the south central Anatolia about $10 \mathrm{~km} \mathrm{W-SW} \mathrm{of} \mathrm{Konya} \mathrm{city} \mathrm{(Fig.} \mathrm{1).}$ The lithological units in the study area are considered to be a part of Afyon-Bolkardağ Zone (Okay, 1986) or the Kütahya- Bolkardağ1 Zone of (Özcan et al., 1988), were affected by Alpine and Paleotethyan (Cimmerian) events (Eren et al., 2004; Özcan et al., 1990).

The Neotethyan ophiolitic units are represented by the Late Cretaceous aged Çayırbağ 1 ophiolites and Hatıp Ophiolitic Mélange in the region. The Çayırbağı ophiolites were made up of dark green to brown colored, variably serpantinized peridotite, massive gabbro, banded gabbro and pyroxenites. In fault zones and along contacts with the country rocks, serpentinization is intensive in the ultramafic rocks. On the basis of serpantinization degree of the ultramafic rocks, Altunel (1963), Zedef (1994) and Zedef et al. (2000) mapped three distinct units in the ophiolites; silicified and carbonated serpantinites, and serpantinized peridotites. Within the ultramafic rocks, large stockwork type magnesite deposits were also developed. The ophiolites obducted onto the Hatıp Ophiolitic Mélange including chert-bearing limestone, mudstone, serpantinite and detritial of ophiolitic rocks. The Neotethyan ophiolitic units obducted onto the Middle Triassic-Upper Cretaceous Lorasdag1 Formation (neritic limestone) to Midos Tepe formation (pelagic carbonates) (Özcan et al., 1990; Figure 2). 


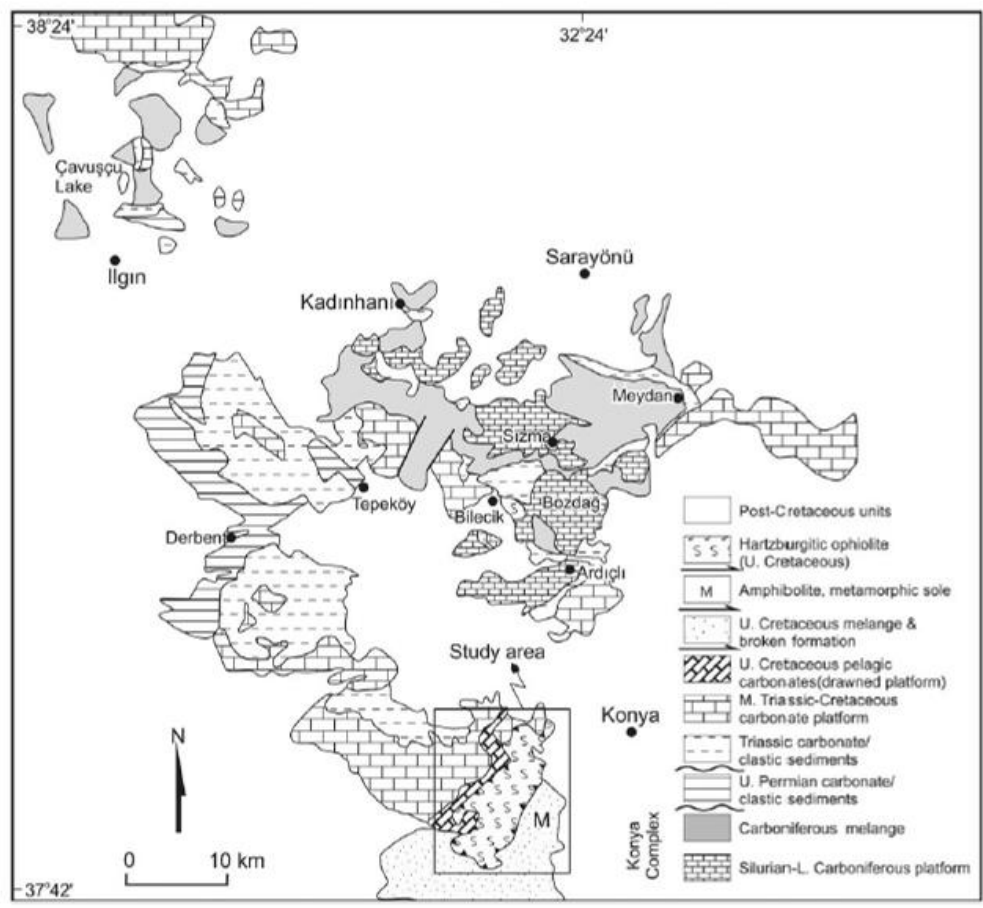

Figure 1. Geological map of the Konya area (modified from MTA,2002)) with the Paleetethyan and Neotethyan units (taken from Robertson and Ustaomer, 2009).

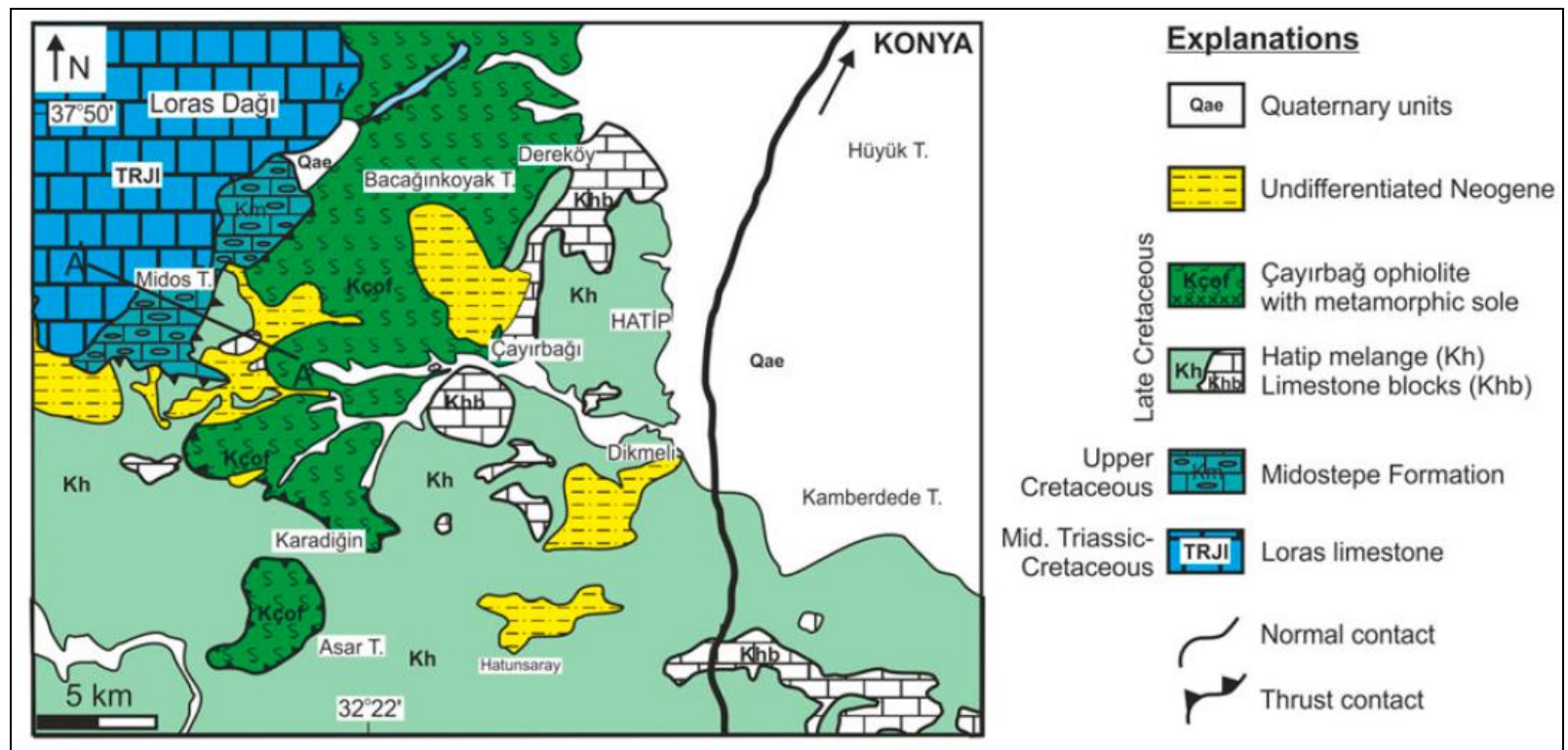

Figure 2. Simplified geological map of the study area in the southwest of Konya city (from Dasci et al. 2015; Özcan et al. 1990).

The metamorphic soles beneath ophiolites were first specifically described by Williams and Smyth (1973) in Newfoundland (Canada). They have restricted thickness; typically extending from a few metres up to $500 \mathrm{~m}$, but thicknesses of over $1 \mathrm{~km}$ have been described (e.g. MacKenzie 1960). In the study area, the metamorphic sole has $\sim 35 \mathrm{~m}$ thickness, and can be observed along a road section between Çayırbağ and 
Karadiğin villages (Dasci et al., 2015). 2-3-m-thick highly sheared serpentinite developed between the metamorphic sole and the overlying peridotite. The metamorphic sole rocks develop as thin slices beneath the sheared serpentinites and harzburgites. The metamagmatic rocks are amphibolite, epidote-amphibolite, zoizite-amphibolite and amphibole-quartzite in composition.

\section{ANALYTICAL METHODS}

From the selected samples, fifty thin sections of were made at thin section laboratory of Department of Geological Engineering (Selçuk University, Konya), and then, their composition and texture were studied under the microscope. Modal mineralogy was determined by point counting (2000-3000 points per thin section, depending on grain size). Polished sections of the samples were analyzed at the Electron Microprobe Laboratory of Middle East Technical University, Ankara/TURKEY. Mineral analyses were carrtied out on a JEOL JSM35 Electron Microprobe running Link QX2000 energy dispersive analytical software, and they are presented in Tables 1 . The electron beam condition was $15 \mathrm{keV}$ and $15 \mathrm{nA}$. Ferric iron estimations were calculated according to Droop (1987).

\section{MINERALOGY}

The amphibole is main constituents in the samples, in addition to the plagioclase, pyroxene, epidote and zoizite. It is subhedral to euhedral prismatic (up to $1 \mathrm{~mm}$ in length) to six-sided hornblende crystals, pleochroic from yellowish-green to brownish (Figure 3) and occasionally altered to calcite and chlorite in a nematoblastic to granonematoblastic texture. The amphibole contains inclusions of epidote, quartz and titanite, and show crystallographic preferred orientation. The sphene can also form as distinct crystals, similar to the other metamorphic soles of the Tauride ophiolites such as Lycian (Koycegiz- Yesilova), Mersin and Pozant1-Karsant1, as well as Beysehir.

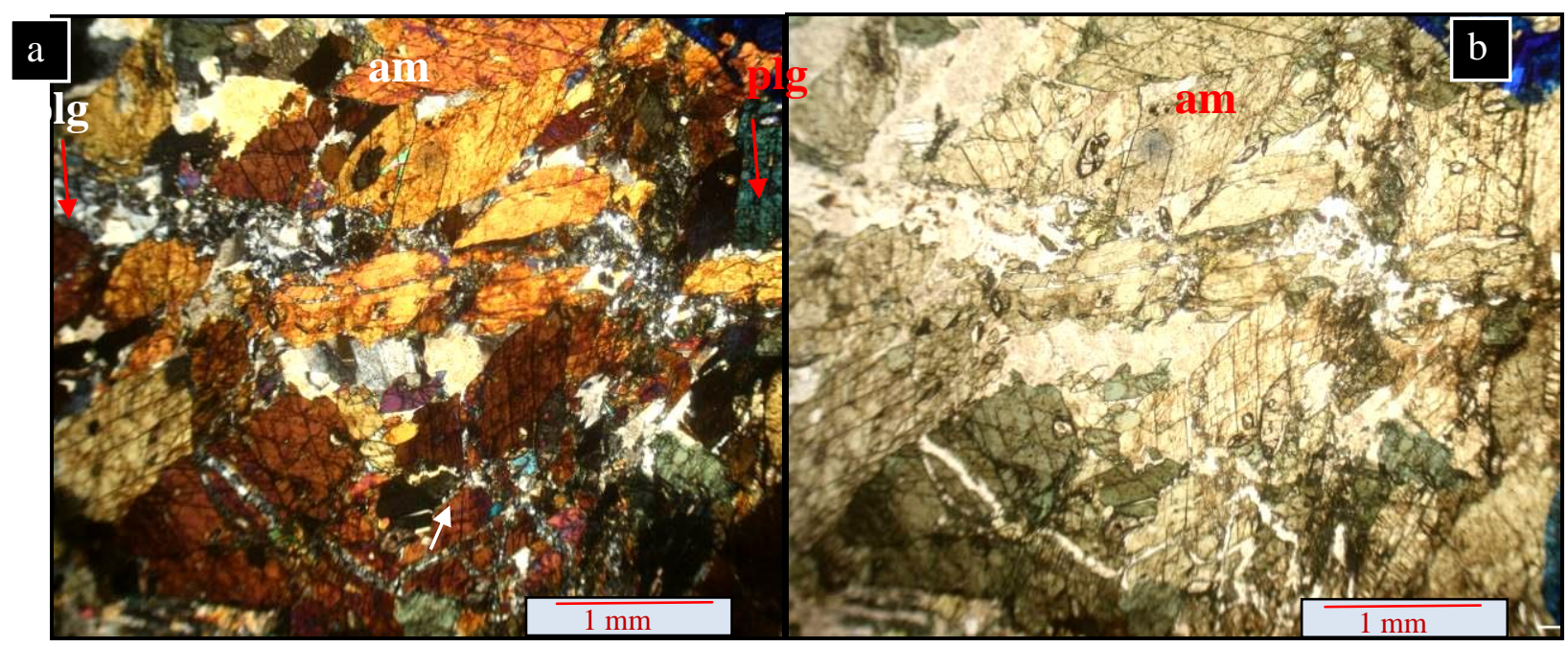

Figure 3. Microphotos of the amphibolites. (a) X Nicols, (b) / Nicol. Plg: plagioclase, am: amphibole 


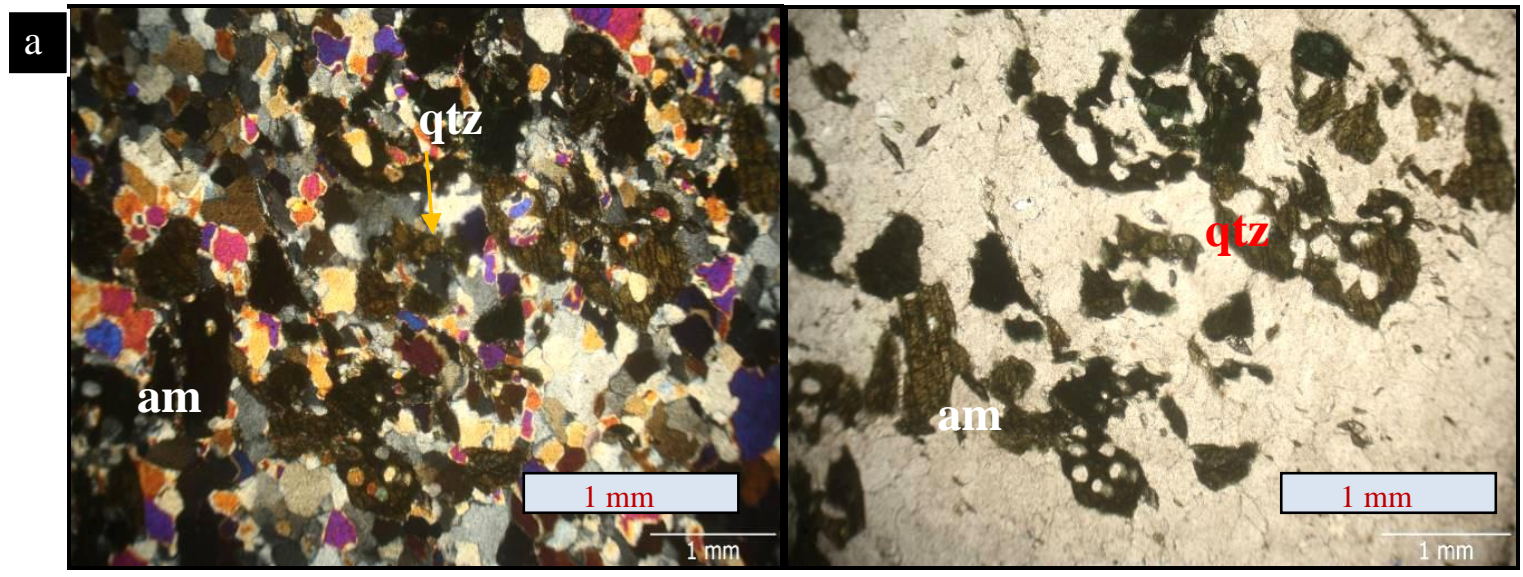

Figure 4. Microphotosy of the quartz-amphibolites. (a) X Nicols, (b) / Nicol. qtz: quartz, am: amphibole

Modal analyses show that amphibole content in the samples vary from 90\% (amphibolite Figure 3), through $65,3 \%$ (epidote-amphibolite), to \%28,5 (amphibole- quartzite,

Figure 4). Results of the chemical analyses of the amphiboles are presented in Table 1. They are characterized by a large variation in AlIV (0.97-1.98 a.p.f.u.) and XMg (0.63-1), and high Na content up to 0.92 a.p.f.u. Si correlate inversely with $\mathrm{Al}, \mathrm{Ti}, \mathrm{Na}$ and $\mathrm{K}$. The amphiboles are in calcic group, and magnesiohornblende, edenite and pargasite based on the nomenclature suggested by IMA 2012 (Hawthorne et al., 2012; Figure 5).

\section{DISCUSSION AND CONCLUSIONS}

Existence of epidote and chlorite, and lack of metamorphic amphibole such as actinolite in the studied amphibolites can suggest that the rocks have experienced the regional metamorphic conditions, which, corresponding to greenschist facies. Therefore, it is unlikely that the amphiboles in the samples are of metamorphic origin. Accordingly, high Si (a.p.f.u.) and relatively low $\mathrm{Ca}+\mathrm{Na}+\mathrm{K}$ content of the amphiboles are in accordance with an igneous composition (Figure 6a). The amphiboles have intermediate to high content of $\mathrm{Na}^{\mathrm{M}}$, suggesting a medium pressure crystallization (Figure 6b). Relatively high $\mathrm{Si}, \mathrm{Al}^{\mathrm{iv}}$ and $\mathrm{Al}^{\mathrm{vi}}$ also suggests that crystallization pressure of the amphibole is $\leq 7 \mathrm{~kb}$ ( Figure $6 \mathrm{c}, \mathrm{d}$ ). Similarly, in tholeiitic Andaman Ophiolite (Andaman-Nicobar Islands, India), 7-8.6 kb crystallization pressure is obtained for the cumulate pyroxenite and gabbro based on clinopyroxene thermobarometry (Saha et al., 2010). Moreover, medium- to high-pressure (up to $10 \mathrm{kbar}$ ) crystal fractionation primary basaltic melts is suggested for ultramafic cumulates of the Pozanti-Karsanti ophiolite in eastern Taurides (Turkey) based on the existence of highly magnesian clinopyroxene and orthopyroxene together with the absence of plagioclase (Parlak et al., 2002). The occurrence of hornblendes appears to be consistent with high P $_{\mathrm{H} 2 \mathrm{O}}$ conditions in the magma (Johannes, 1978). Dasci et al. (2015) suggest that the metabasic rocks were derived from the alkaline (seamount) and tholeiitic (E-MORB, IAT and boninitic type) magmatic rocks from the upper part of the Neotethyan oceanic crust. 

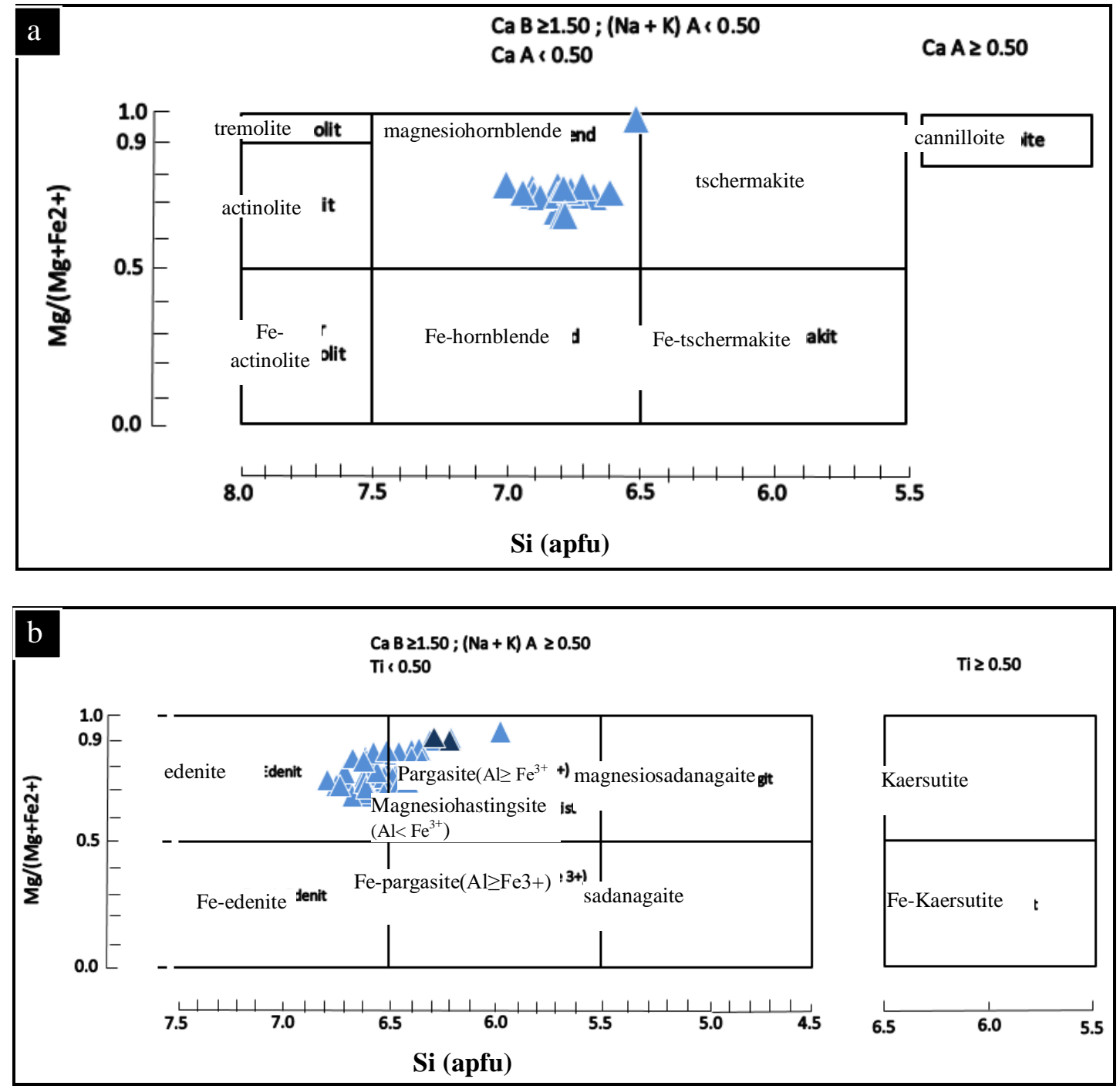

Figure 5. Nomenclature (after Hawthorne et al., 2012) of the amphiboles $\left(\mathrm{Al}>\mathrm{Fe}^{3+}\right)$ in the studied amphibolites a) $\mathrm{Ca} B \geq 1.50$; (Na+K) $\mathrm{A}<0.5$, b) $\mathrm{Ca} B \geq 1.50$; (Na+K) $\mathrm{A} \geq 0.5$ 
of The Late Cretaceous Aged Hatip Ophiolitic Mélange in The Konya Area (Central Southern Turkey)

Table 1. Representative microprobe analyses of the amphiboles in the studied amphibolites.

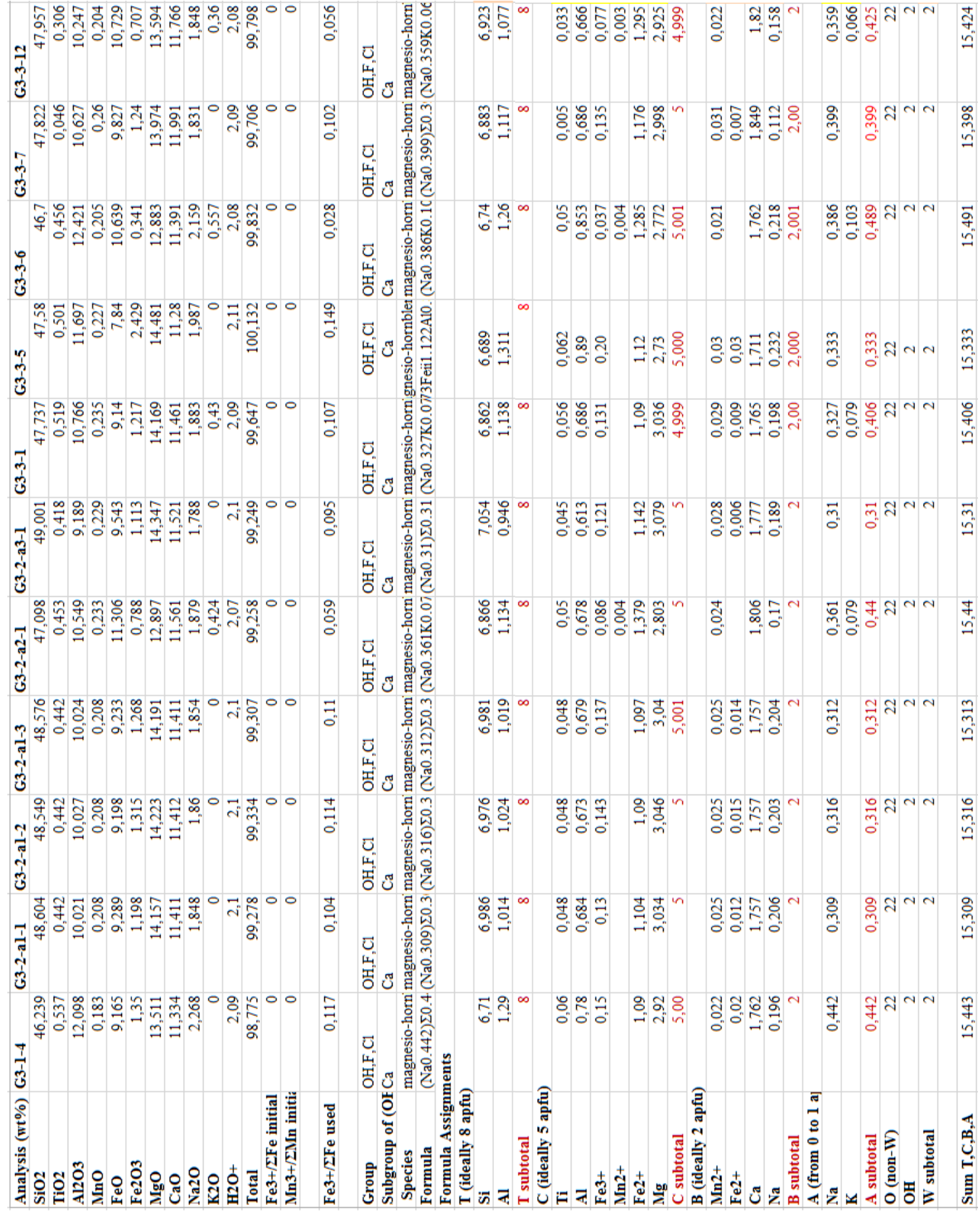

In conclusion, the studied metaigneous rocks from the Cayırbagı ophiolitic mélange were experienced a regional metamorphism in greenschist facies condition, that has not altered the chemical composition of the igneous amphiboles; namely magnesiohornblende, edenite and pargasite. The amphiboles crystallized from 
a wet magma in medium pressure conditions $(\leq 7 \mathrm{~kb})$ to form the upper part of the Neotethyan oceanic crust.
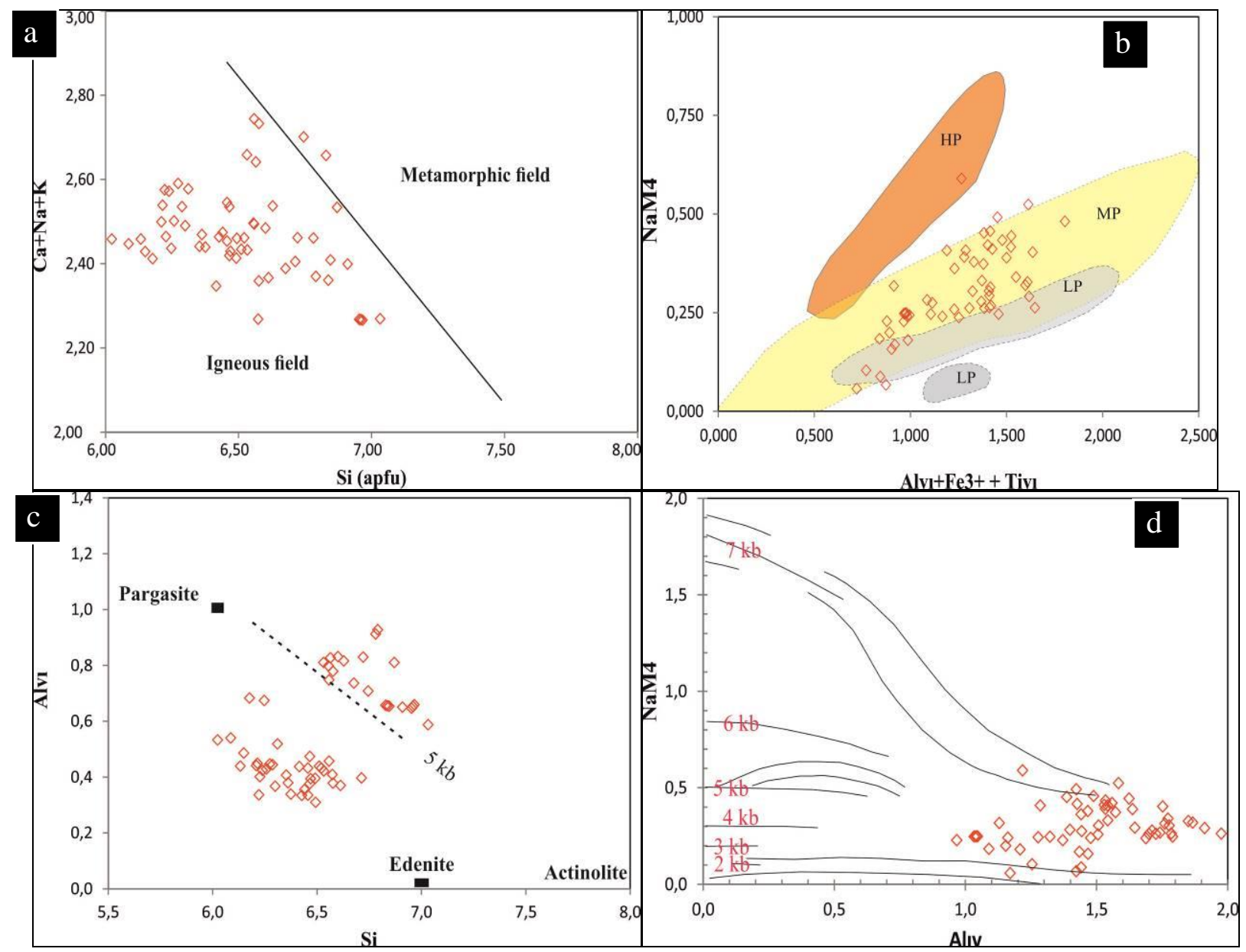

Figure 6. Compositional variations of the amphiboles in the studied amphibolites.

(a) $(\mathrm{Ca}+\mathrm{Na}+\mathrm{K})$ vs $\mathrm{Si}(\mathrm{apfu})$ diagram after Giret et al. (1980),

(b) $\mathrm{Na}\left({ }^{\mathrm{M} 4}\right) \mathrm{vs} . \mathrm{Al}^{\mathrm{v}+}+\mathrm{Fe}^{3+}+\mathrm{T}^{\mathrm{v}}$ plot. High (HP), medium (MP) and low pressure (LP) fields as defined by Laird and Albee (1981),

(c) $\mathrm{Al}^{\mathrm{VI}}$ vs Si diagram after Raase (1974),

(d) $\mathrm{Na}\left(\mathrm{M}^{4}\right)$ vs. $\mathrm{Al}^{\text {iv }}$ plot. Fields as defined by Brown (1977).

\section{ACKNOWLEDGE}

This work is a part of MSc study of second author who acknowledges financial support from the Selçuk University Research Foundation.

\section{REFERENCES}

Altunel, E., 1963, "Ilgin-Konya Sheet: 1:500,000". In: I.o.M.R.a. Exploration (Editor).

Brown, E.H., 1977, "The Crossite Content of Ca-Amphibole as a Guide to Pressure of Metamorphism", Journal of Petrology, Vol. 18, pp. 53-72. 
Dasci, H.T., Parlak, O., Nurlu, N., Billor, Z., 2015, "Geochemical Characteristics and Age of Metamorphic Sole Rocks within a Neotethyan Ophiolitic Melange from Konya Region (Central Southern Turkey)", Geodinamica Acta, Vol. 27(4), pp. 223-243.

Droop, G. T. R., 1987, "A General Equation for Estimating Fe-3+ Concentrations in Ferromagnesian Silicates and Oxides from Microprobe Analyses, Using Stoichiometric Criteria", Mineralogical Magazine, Vol. 51(361), pp. 431-435.

Eren, Y., 1993, "Konya Kuzeybatısında Bozdağlar Masifinin Otokton ve Örtü Birimlerinin Stratigrafisi (in Turkish)", Geological Bulleten Turkey, Vol. 36, pp. 7-23.

Eren, Y., Kurt, H., Rosselet, F., Stampfli, G.M., 2004, "Palaeozoic Deformation and Magmatism in the Northern Area of the Anatolide Block (Konya), Witness of the Palaeotethys Active Margin", Eclogae Geologicae Helvetiae, Vol. 97(2), pp. 293-306.

Giret, A., Bonin, B., Leger, J.M., 1980, "Amphibole Compositional Trends in Oversaturated and Undersaturated Alkaline Plutonic Ring-Complexes", Canadian Mineralogist, Vol. 18, pp. 481-495.

Goncuoglu, M. C., Capkinoglu, S., Gursu, S., Noble, P., Turhan, N., Tekin, U. K., Okuyucu, C., Goncuoglu, Y., 2007, "The Mississippian in the Central and Eastern Taurides (Turkey): Constraints on the Tectonic Setting of the Tauride-Anatolide Platform", Geologica Carpathica, Vol. 58(5), pp. 427-442.

Hawthorne, F. C., Oberti, R., Harlow, G. E., Maresch, W. V., Martin, R. F., Schumacher, J. C., Welch, M. D., 2012, "Nomenclature of the Amphibole Supergroup", American Mineralogist, Vol. 97(11-12), pp. 20312048.

Johannes, W., 1978, "Melting of Plagioclase in the System Ab-An-H2O and Qz-Ab-An-H2O at PH2O=5 Kbars, an Equilibrium Problem", Contributions to Mineralogy and Petrology, Vol. 66, pp. 295-303.

Laird, J., Albee, A.L., 1981, "Pressure, Temperature, and Time Indicators in Mafic Schist - Their Application to Reconstructing the Polymetamorphic History of Vermont", American Journal of Science, Vol. 281(2), pp. 127-175.

MTA, 2002, "1/500 000 Scale Geological Maps of Turkey. General Directorate of Mineral Research and Exploration, Ankara.

Mackenzie, D. B., 1960, "High Temperature Alpine-type Peridotite from Venezuela", Geological Society of America Bulletin, Vol. 71, pp. 303-18.

Okay, A. I., 1986, "High-pressure/low Temperature Metamorphic Rocks of Turkey", Geological Society of America Memoirs, Vol. 164, pp. 338-348.

Özcan, A., Göncüoğlu, M.C., Turhan, N., Şentürk, K., Uysal, Ş., Işık, A., 1990, Konya-Kadınhanı-Ilgın Dolayının Temel Jeolojisi (in Turkish), MTA Genel Müdürlüğü Jeoloji Etütleri Dairesi.

Özcan, A., Göncüoğlu, M.C., Turhan, N., Uysal, S., Şentürk, K., 1988, "Late Palaeozoic Evolution of the Kütahya-Bolkardağ Belt.", METU Journal of Pure and Applied Science, Vol. 21, pp. 211-220.

Parlak, O., Hock, V., Delaloye, M., 2002, "The Supra-subduction Zone Pozanti-Karsanti Ophiolite, Southern Turkey: Evidence for High-Pressure Crystal Fractionation of Ultramafic Cumulates", Lithos, Vol. 65(1-2), pp. 205-224.

Raase, P., 1974, "Al and Ti Contents of Hornblende, Indicators of Pressure and Temperature of Regional Metamorphism", Contributions to Mineralogy and Petrology, Vol. 45(3), pp. 231-236.

Robertson, A. H. F., Ustaomer, T., 2009, "Formation of the Late Palaeozoic Konya Complex and Comparable Units in Southern Turkey by Subduction-Accretion Processes: Implications for The Tectonic Development of Tethys in the Eastern Mediterranean Region", Tectonophysics, Vol. 473(1-2), pp. 113148.

Saha, A., Dhang, A., Ray, J., Chakraborty, S., Moecher, D., 2010, "Complete Preservation of Ophiolite Suite from South Andaman, India: A Mineral-Chemical Perspective", Journal of Earth System Science, Vol. 119(3), pp. 365-381. 
Williams, H., Smyth, W. R., 1973, "Metamorphic Aureoles Beneath Ophiolite Suites and Alpine Peridotites: Tectonic Implications with West Newfoundland Examples", American Journal of Science, Vol. 273, pp. 594-621.

Zedef, V., 1994, The Origin of Magnesite in Turkey, a Stable Isotope Study, Glasgow University, Glasgow, UK, $159 \mathrm{pp}$.

Zedef, V., Russell, M. J., Fallick, A. E., Hall, A. J., 2000, "Genesis of Vein Stockwork and Sedimentary Magnesite and Hydromagnesite Deposits in the Ultramafic Terranes of Southwestern Turkey: A Stable Isotope Study", Economic Geology and the Bulletin of the Society of Economic Geologists, Vol. 95(2), pp. 429-445. 